Scientia Militaria vol 44, no 1, 2016, pp 22-34. doi: 10.5787/44-1-1160

\title{
The War on War League: A South African Pacifist Movement, 1914-1915
}

\author{
Jonathan Hyslop •
}

\begin{abstract}
The outbreak of the First World War divided the South African Labour Party, a movement representing the country's white working class. The party's parliamentary delegation supported South African government's participation in the war effort, but many leadership figures within the party and the trade unions disagreed with this stance. The dissidents formed an organization called the War on War League. In mid-1915, the anti-war activists left the party and formed the International Socialist League, a predecessor of the Communist Party of South Africa. The War on War League has conventionally been regarded as important only for its role in the eventual formation of the Communist Party. This article however contends that it needs to be understood in its own terms, as a pacifist movement, reflecting a political moment of resistance to the plunge into global war.

Keywords: War on War League, South Africa, Pacifism, Anti-War Movement, First World War, Syndicalism, Internationalism, Witwatersrand
\end{abstract}

\section{Introduction}

Shortly after the outbreak of the First World War, a group of mainly British immigrant socialists and pacifists in the Johannesburg area formed a movement called the War on War League (WoWL), to oppose South African participation in the conflict. ${ }^{1}$ Small as it was, the League was to have surprisingly important effects on subsequent South African history. This article seeks to explain what the League was and why it mattered.

The League, if mentioned at all by historians, is usually seen as significant for one reason only: in late 1915 it turned itself into the International Socialist League (ISL), which in turn went on to constitute the main component in the founding of the Communist Party of South Africa (CPSA). That party, after going underground when it was banned in 1950, in turn morphed into the South African Communist Party (SACP), which became a leading - some would say the leading - force in the ANC's underground struggle against apartheid and especially in its guerrilla wing. Since 1994 the SACP has played a major role in the ANC government.

But this is an unacceptably teleological way of thinking about the League. In a persuasive critique of the influential Communist Party school of historians, ${ }^{2}$ Lucien van der Walt has demonstrated that they have tended to see the First World War as marking a break from a white labour movement which combined racism and the eclectic, radical form of trade unionism known as syndicalism, and a turn toward racial egalitarianism and a 'pure' Marxism, reaching fruition in the CPSA. But, Van der Walt

Colgate University, Hamilton, New York and University of Pretoria. 
shows, reality was a great deal more messy: South Africa's pre-war socialists had a wide divergence of views on racial issues, while the Communist Party's early years were by no means free of racism. And far from immediately embracing the Leninist version of Marxism, the party often hewed to syndicalist ideas until the mid-1920s. ${ }^{3}$ The ISL cannot therefore be seen as simply a stepping stone to the future communist movement. And that is even less the case with the WoWL.

Yet I want to go a step further than van der Walt, and to suggest that the WoWL needs to be understood as a pacifist movement in its own right. It was not, at first, an attempt to create a new labour politics, but rather a product of a deeply felt loathing of war, which looked in many directions for inspiration. The War on War League contained a remarkably varied mélange of ideas. Many of these resonated with the thinking of the pacifist opposition to the war in Britain, the history of which has been so powerfully connected to military history by Adam Hochschild in his recent popular book, To End All Wars. $^{4}$

The WoWL's response to the war was one of visceral rejection. I would suggest that the emotionality of this response needs to be placed in the context of the devastating experience of the 18991902 Second Anglo-Boer War. That conflict had had seen the use of concentration camps, the spread of epidemic disease, the destruction of farms and herds and massive social disruption. A number of War on War members were veterans of that catastrophe, and others had seen its results. These were men and women who felt that they could not in good conscience endorse a repeat of the horrors they had witnessed, this time on a vastly greater scale.

\section{Southern African Politics and British Immigrants before the First World War}

Although the War on War League had a few supporters who were East European Jews, and a few who were Afrikaners, it was mainly based on British immigrant workers and intellectuals. It will therefore be useful to say something about British immigration to the region in this period. From the beginning of British colonization during the Napoleonic Wars, to the 1870s, southern Africa had undoubtedly been the least attractive of the destinations for United Kingdom migrants. The coming of the ' 1820 Settlers' in the Eastern Cape and the 'Byrne settlers' in mid-nineteenth century Natal were very unusual events. But this had changed a little with the development of the Kimberley diamond fields in the 1870s and the Transvaal goldfields in the 1880s. And with industrialization of Transvaal gold mining, United Kingdom immigration soared between 1890 and 1906, as southern Africa for a time rivaled Australia as a destination for British immigrants. As a consequence there was a rapid growth of a British working class in the region, and especially on the Witwatersrand goldfields. ${ }^{5}$ With this transplantation came the full range of current British political ideas, including socialism and labour political representation. Immigrants formed political organizations and unions; some of them were even branches of UK organisations skilled engineering artisans in South Africa for example, were actually organized as members of the British Amalgamated Society of Engineers (ASE). By the time of the outbreak of war in 1914, white workers on the Rand were grouped in a number of strong trade unions, under the umbrella of the Industrial Federation. The Federation was presided over by the ASE's W.H. Andrews, a Suffolk-born engineering worker who had served in an imperial regiment during the Second Anglo-Boer War. However, British political ideas were being inserted into a new, colonial context. On the mines, while British workers occupied the skilled jobs, most of the basic labour was performed by black (and for a brief period, Chinese) men. So British workers tended to fear that they would be replaced by cheaper, 
colonized workers. And this anxiety was reflected in their political representation. In 1909 the unions formed the South African Labour Party (SALP) which focused politically around the notion that white workers' wages needed to be protected against Asian and African competition. The leader of the SALP, F.H.P. Creswell, was an upper middle class mining engineer with a strong personal commitment to promoting the use of white labour. There were though, also a number of small socialist groups, who did not share this white labour protectionist position. ${ }^{6}$

The First World broke out at moment when the South African state was still in a formative and fragile phase. In 1910, Britain's Liberal government had permitted the four self-governing colonies of the region to come together in a single state. But that state seemed to many to have an uncertain future. The franchise had been placed in the hands of an almost exclusively white electorate; only in the Cape Province did a number of black men enjoy the right to vote on a selective franchise. Even then, looking at a society in which black people outnumbered whites four to one, many a foreign observer wondered how this would ever be the 'White Man's Country' which the dominant political parties declared they were creating. The government, headed by Prime Minister Louis Botha and his right hand man Jan Smuts, claimed to be uniting Afrikaners with British settlers and overcoming the bitter legacy of the recent War. But by 1912 J.B.M. Hertzog led a breakaway of unreconciled Afrikaners to form the National Party.

Between 1912 and August 1914, the state faced three notable challenges. Firstly, Botha's policy of dividing the land on a racial basis, with the lion's share going to the whites, provoked the black elite, both modernist intellectuals and traditional chiefs, into organizing politically. These leaders created, in 1912, the South African Native National Congress (SANNC), later the ANC. A movement that greatly valued its respectability, the SANNC focused on a strategy of lobbying the British government to intervene in South Africa. This was an embarrassment to Botha in the context of imperial politics. Secondly, the Indian immigrant community in South Africa, under the leadership of M.K. Gandhi, mounted a spectacular series of strikes and labour revolts in late 1913. These protests led to direct criticism of the Pretoria administration by the Viceroy of India and apparent concessions to Gandhi by Smuts. Thirdly, and most dramatically though, the British immigrant and Afrikaner working class in the mines, railways and factories of the Witwatersrand became insurgent over wages, conditions and union recognition. In mid-1913 there was a general strike of white labour on the Rand. After street fighting and the killing of over twenty people by the British army garrison, Botha and Smuts humiliatingly acceded to the strikers' demands. But they gained their revenge the next year. When a second strike was attempted, Smuts declared martial law, mobilized the newly created Union Defence Force, and crushed the strike. Nine strike leaders were deported to the United Kingdom, causing a huge wave of trade union protest there. There was a massive popular backlash by white voters against these heavy-handed actions, and in March 1914, the SALP captured control of the Transvaal legislature in the provincial elections. Both trade unionists and the SALP believed they were making headway in gaining the support of newly urbanized Afrikaners. ${ }^{7}$

\section{The Outbreak of War}

But this political configuration was to be dramatically changed by the war. The South African Native National Congress declared its support for the Empire, with chiefs recruiting men as labourers for the army. The Congress's leading intellectual, Sol Plaatje, thought that loyalty would be rewarded by Britain with pressure for post-war liberalisation in South Africa, a hope that was to be disappointed. When Plaatje 
went on a wartime speaking tour of the UK, one of his posters proclaimed the slogan 'Brotherhood and Empire' ${ }^{8}$ Gandhi was by now in the United Kingdom, but he and his South African followers also rallied to support the British war effort. And there was also a wave of loyalist sentiment amongst British immigrants which seemed to have taken the energy out of labour protest. All of this gave much-needed political breathing space to Botha and Smuts.

On the other hand, Afrikaner nationalists were largely unwilling to fight for the old enemy. While Hertzog and most of the parliamentary leaders limited themselves to verbal objections to participation in the war, a group of Afrikaner military leaders, including the legendary General Christiaan De Wet, staged an armed uprising in the western Transvaal and northern Free State. ${ }^{9}$ Although this insurgency was eventually put down, it was a serious threat to Botha and Smuts while it lasted.

The response of the South African Labour Party to the war was crucial to Botha and Smuts. When Britain entered the conflict, the Botha-Smuts government had taken the view that as part of the empire, South Africa was automatically at war with Germany. With a rural Afrikaner revolt looming, Smuts, as Minister of Defence, desperately needed the support of the British immigrant urban workers, many of whom were members of the army's citizen force militia regiments. However, the government had reason to be concerned about labour's backing. The SALP became affiliated to the International Socialist Bureau in 1913, and had endorsed the anti-war position of the European socialist parties. ${ }^{10}$ On 2 August 1914, two days before the British declaration of war, the Administrative Council of the SALP, chaired by W.H. Andrews, resolved to express its "protest against the capitalistic Governments of Europe in fomenting a war which can only benefit international arms manufacturers' rings and other enemies of the working classes", while the SALP-aligned trade union group, the Industrial Federation, passed a resolution condemning the war. ${ }^{11}$ Fortunately for the regime, SALP leader Creswell was determined to support the war effort. The party paper, The Worker, came out in favour of imperial loyalty, signaling a divergence between the supporters of Andrews and those of Creswell. ${ }^{12}$ The Creswellites mobilized to pass pro-war resolutions in numerous SALP branches, and some even floated the idea of recruiting 'Labour Legions'. ${ }^{13}$ By October, the Industrial Federation had reversed its position, and joined the pro-war camp.

\section{The War on War League}

Philip Roux, an Afrikaner pharmacist, seems to have played a key role in developing an anti-war politics on the left in South Africa. Roux was a member of a small band of labour activists who were followers of the American Marxist theorist Daniel de Leon. The other members of this group whom I have been able to identify were Scottish, and this is explained by the fact that as there was a small but vigorous De Leonist party in the Glasgow area. Glasgow was a particularly strong source of immigration to the Rand. (The Glasgow De Leonists, incidentally, were for a time headed up by the future Irish national martyr of the 1916 Dublin Easter Rising, James Connolly). ${ }^{14}$ Shortly after the beginning of the war, Roux invited a number of acquaintances, including several SALP members, to meet at his shop in the Johannesburg suburb of Bezuidenhout Valley. Roux took an uncompromising anti-war stance. S.P. Bunting, a Labour member of the provincial legislature, was wavering on whether to support the war. Roux later recalled saying to Bunting: "there was only one attitude to assume: tell the workers that they are only a pawn in the game the capitalists call war". ${ }^{15}$ Bunting was won over, and became one of the main pillars of the anti-war group. The son of a prominent liberal editor in London, and a graduate of Magdalen College, Oxford, Bunting had come to South Africa as an officer in the Second Anglo-Boer War. He had settled in 
Johannesburg where he worked as a lawyer, and had only recently been won over to the Labour cause. In September another SALP Member of the Transvaal Legislative Assembly, a dentist by the name of Colin Wade, issued a leaflet in the mining town of Germiston, calling for "War on War". ${ }^{16}$ Wade's supporters quickly formed a committee, led by himself, Philip Roux, and Bunting, and they constituted themselves as the 'War on War League'. The League took a universal pacifist position, declaring its commitment to "oppose this war and any other war at all times and at all costs". ${ }^{17}$ In other words they were objecting to war in general, not just this war in particular.

Also prominent in the WoWL was another Oxford graduate, a Unitarian minister, the Reverend R.J. Hall, the Principal of the Johannesburg Workers Educational Association. The WEA was a group which was supported by the industrial unions, but hedged its ideological bets by also having the Governor-General as patron. Hall ran a demanding progamme of courses in Sociology, Ethnology and English and American History, Literature and Comparative Religion, which reflects the remarkable literacy and interest in self-improvement amongst the British artisans of this era. Much of the reading was of mainstream liberal British writers such as Buckle, Spencer, and Bagehot. But more radical perspectives were represented in the syllabus by the works of the anarchist scholars, Kropotkin and Reclus. ${ }^{18}$

W.H. Andrews was invited to join the WoWL but, despite his anti-war views, decided against it. Looking back from the perspective of the 1940s, Andrews claimed that, in his view at the time, WoWL was, in the words of his biographer, an organization of "middle class professional men, clerks, clergymen and others whose mental honesty and humanitarianism had brought them over to the side of the workers. Few of them were working class". ${ }^{19}$ In fact this was not an accurate representation, for the League did have some of the most prominent Rand trade unionists as members. But as a leader with a strongly pragmatic streak, Andrews was reluctant to risk his position at the centre of the British immigrant labour movement, or to split it over the issue of war. ${ }^{20} \mathrm{He}$ was also sceptical of a universal pacifist position, saying that he could foresee the necessity to fight a war on behalf of the working class. ${ }^{21}$

In September, parliament reconvened in Cape Town to discuss a Government motion of loyalty to the Crown. By this time, the SALP had eight seats in the house, the delegation including Creswell and Andrews. Creswell had great difficulty in getting the rest of the SALP members to join him in backing the motion because of their strong anti-war feeling. In order to win their support, Creswell spoke denouncing war in general terms, and proposing an amendment in favour of the future reduction of armaments and use of arbitration to resolve international disputes. But he later withdrew the motion. By this time the Botha government, and the request of the imperial authorities, was preparing a military expedition to conquer the German colony of South-West Africa (now Namibia). On behalf of the SALP, Creswell accepted the government's assurance that they were not planning to annex the territory - a pledge which proved valueless when at the post-war Versailles conference, South Africa received the territory as a League of Nations mandate, and began a long campaign to be permitted to incorporate it. Only one of the Labour members, Walter Madeley of Benoni, failed to support the loyalty motion, and he soon repented of his decision. ${ }^{22}$ The SALP's cooperation was made easier by Botha's decision to allow the deported trade unionists to return from England, as a gesture to conciliate the party and the unions.

The WoWL launched a series of public meetings in Johannesburg. The members struggled for some time to find a regular venue, but eventually secured the Tivoli Theatre for gatherings every Sunday night. At one of the earlier meetings, held in the Old Market Hall on the evening of 6 September, the Chair was taken by J. Forrester Brown, an Australian organizer for the Transvaal Miners Association. The gathering was attended by about 700 people. Speakers included Wade and Bunting, as well as a 
pugnacious Scottish syndicalist blacksmith, Andrew Dunbar. Police Sergeant J. Lyons reported that the speakers took a strongly anti-capitalist position, as well as condemning what they called 'military despotism'. ${ }^{23}$ Interestingly Lyons' report suggests that the activists were already talking about an "international Socialist organisation", an idea that would only really emerge into the light of day much later. But certainly for the moment, most League activists appear to have seen their future as within the SALP. Such meetings were not massive, but they were big enough to be troubling to a government which now needed to rely on the loyalty of British immigrants against the disaffection of insurgent Afrikaner nationalists. Proselytizing against the war was a risky activity. In November 1914, Dunbar was sentenced to a then enormous fine of $£ 100$ or twelve months hard labour by a magistrate, for his speech at one meeting. ${ }^{24}$ At a subsequent meeting a fight broke out, leading to the arrest of Bunting, Dunbar and a Welsh leftist activist named David Ivon Jones; charges however were dropped after a long delay. The League also supported the Cape Town socialist and former soldier in the Coldstream Guards, Wilfrid Harrison, who was sentenced for his anti-war agitation. ${ }^{25}$ Harrison was another veteran of the Second Anglo-Boer War. His fine was paid by public subscription.

Most importantly, the League brought out a regular periodical, the War on War Gazette, which published eleven editions between the organization's founding and the end of November 1914. It was printed at the Modern Press in Fox Street, Johannesburg, a company owned by the combative Irish syndicalist, 'Pickhandle Mary' Fitzgerald and her partner, the deported trade unionist Archie Crawford. Although meticulously produced, the Gazette cannot be said to have been well written. Bunting, who would develop into a formidable political writer in future years, had the advantage of a superb formal education, but was as yet inexperienced in pamphleteering, and none of his colleagues was particularly talented in this department, though there were a number of powerful speakers among them. The articles by WoWL members tended to have a rambling character to them. It also seems clear from the paper's financial contribution column that the War on War Gazette was reliant on a small circle of donors. Yet the Gazette reflected the ardour of the movement it represented, and it drew a line of principle against the war. Certainly, the authorities were anxious to shut it down. There was also another journalistic outlet for anti-war sentiment. This was a broadly socialist paper, the Eastern Record, produced in Benoni on the East Rand by two Scottish immigrants, Christina and Robert Barnet. Robert Barnet was an accountant and was apparently able to find the funds to sponsor the launching of the paper. The Barnets were motivated in this project by their desire to respond to the government repression of the strikers in early 1914. Eastern Record was a considerably more entertaining and more stylishly edited production than the Gazette. It carried quite a number of contributions by the Rand's anti-war socialists, as well as providing a sceptical view of the Creswell wing of the SALP leadership and its 'white labour' ideology. The Record was not to survive beyond 1915, but it was a remarkable venture while it lasted.

The notions that influenced the League came from a wide range of sources, as the pages of the War on War Gazette reveal. The paper includes articles by the League's leading figures, giving their personal views on the need for opposition to the war. But the Gazette also published numerous extracts from the works of anti-war authors across the ideological spectrum, from conservatism through liberalism to socialism and anarchism. Thus one finds in its pages, for example, extracts from culture-heroes as diverse as Carlyle, Tolstoy, Mark Twain, and Whitman, pieces from prominent contemporary intellectuals such as Goldsworthy Lowes Dickinson and Clarence Darrow, and a serialization of the anarchist Kropotkin's 'Wars and Capitalism'. Here it would seem, one sees the liberal intellectuals and radical trade unionist artisans of 1914 rummaging through the attics of their wide reading to deploy everything 
they can find to make the anti-war case. The content very much reflects the kind of intellectual world represented by the Workers Educational Association, in which the earnest, educated middle classes like Hall, were in conversation with a remarkably literate group of artisans. The emphasis of the Gazette then, was not on ideological consistency, but on invoking as wide a range of authorities as possible against the legitimacy of war. The magazine also contains numerous anti-war quips, factoids, and jokes. There was a strong stand of socialist critique of nationalism in the paper as well. One editorial argued for "the close connection of capitalism, militarism and nationalism". ${ }^{26}$ Another article urged that "The hope of the world after the war rests on the co-operation, not of the Socialists who have been shooting at each other: but of the real militants, the faithful, the War on War League of all countries." 27 In a defiantly internationalist gesture, articles in the Gazette expressed admiration for Karl Liebknecht, the leader of the small group of German socialists who had held out against supporting the war. ${ }^{28}$ Moreover, the paper reflected that the Johannesburg radicals closely read and discussed the international English language socialist press, with quotations appearing from papers including the American Appeal to Reason and the Glasgow Forward. ${ }^{29}$

Racial politics was relatively absent from the publication, given its prevalence in the SALP's discourse. An exception was a comment by Dunbar, who in an article in the Gazette predicted the aftermath of the war: "When you come back, you find - a n.... doing your job for half a dollar a day". ${ }^{30}$ But this was an isolated instance of overt racism in the Gazette. The anti-war faction generally attracted the more racially egalitarian thinkers in the SALP and the left, like Bunting and the deportee George Mason. What was the central feature in regard to race though, was that the debate was conducted mainly as one amongst white people, in which little attention is paid to the politics of empire. The participants put forward their views as if they are simply part of the debate on the war in Europe, and gave little recognition to the demographic realities of the country in which they lived. Racial ideology functioned not through an overt racial antagonism, but through thinking which largely ignored the existence of the black majority.

Even more troubling, perhaps, was a deeply mysoginistic strain in Colin Wade's personal version of anti-war ideology. At a November public meeting in Johannesburg, he argued that as a result of the war, hundreds of thousands of women, would be

thrown on the labour market where formerly their husbands, fathers and brothers were employed. Some
will only find employment by doing the same amount of work as men for less wages: thus inevitably
forcing down the already too low standard of living. Others again will only be able to obtain the necessaries
of life through the practice of prostitution and thereby spread the occupational disease of syphilis. The
average stature of man will less than it [is] now. In the non-conscript countries like England it will be the
physically best men who will have to die and leave the propagation of the race to the unfit. Possibly the
marriage laws will have to be altered owing to the vast predominance of females over males in the
population. ${ }^{31}$ While it is not surprising that Wade shared the eugenic ideas which were present even in the left at the turn of the century, the rapid connections made between women replacing men in industry, syphilis, male height and a presumably polygamous dystopia suggest both an anxiety over gender authority and a set of personal psychological discontents which complicate any temptation to picture Wade as a simple and selfless activist.

The Emergency powers taken by the government gradually stifled the publication of the Gazette. The Chief Censor, Hugh Wyndham, a British aristocrat and sometime official in Lord Milner's post-Boer War administration, who had settled in the Transvaal, went after the publication with considerable 
enthusiasm. Reputedly, when Bunting complained to Wyndham that he had been forbidden to publish the Sixth Commandment, Wyndham replied "The Bible is a most dangerous book, Sir". ${ }^{2}$ By the end of November 1914 the editors found that it had been made impossible for them to continue publishing the Gazette. ${ }^{33}$

Apart from the broad ethical and socialist arguments that could be made against the war, the WoWL pointed to the divisiveness between Anglophones and Afrikaners that the war was likely to rekindle, as a danger. Although a substantial number of Afrikaners were to serve in the army during the war, surely very few felt much ideological enthusiasm for doing so; hardly surprising, considering that their own war with the British had been concluded a mere twelve years before. This might have been thought to be an argument that would have been expected to appeal to Labourites: at the 1914 election, the party had shown signs of being able to take Afrikaner votes, a development which would be blocked off by wartime ethnic division. But although Bunting pointed out the negative implications of supporting the war for the party's electoral future, British loyalism amongst the SALP's supporters was ultimately too intense to be turned by this argument.

With the outbreak of the Afrikaner Rebellion, the League tried to cast itself as a peace-maker between the rebels and the government. In this, WoWL was motivated not only by pacifism, but also by a nascent sense of South African patriotism. The War on War Gazette wrote that:

We want to see South Africa, whatever her attitude on the German war come out solid for peace among her own people. Thank God, this is a situation, unlike that in Europe, which the people themselves can still mould. Not by sitting still, but by building up a public opinion ... that both Government and rebels will begin to hearken to ... and will recoil at the shedding of one drop of South African blood. ${ }^{34}$

British immigrant communities in South Africa were beginning to form new, more locally rooted identities. In the case of the British socialists, this was surely accelerated by their disillusion with the policies of successive British governments in the post-1902 era, and by their pleasant surprise at the support the unions and the SALP had enjoyed amongst some Afrikaner workers in the 1913 strikes and the 1914 Transvaal provincial elections. It is notable that whereas before the war, labour organizers had still often appealed to an idea of their rights as British citizens, such claims were largely absent in the Gazette.

On 27 October, the WoWL executive wrote to the Governor General, Lord Buxton, offering Wade's services as a mediator with the Afrikaner rebels, and asking him to receive a delegation to discuss the proposal. But the very next day, Buxton's secretary dismissed the proposal out of hand. ${ }^{35}$ Two days later, Advocate Frank Lucas, a SALP Transvaal Provincial Council member, travelled to the Free State capital of Bloemfontein on behalf of the League, to meet with Afrikaner politicians in order to pursue negotiations. But with the elusive Hertzog absent from the town, nothing firm could be decided. A WoWL meeting of four hundred in Johannesburg called on the Governor General to reconvene parliament in order to head off the crisis, and Roux followed this up on 11 November with a letter to Buxton. He also wrote to Hertzog asking for clarification of his position, but neither appeal seems to have evoked a significant response. ${ }^{36}$ 


\section{The Battle in the SA Labour Party and Trade Unions}

Despite these setbacks, the influence of the anti-war position within the SALP leadership grew. On the Transvaal Provincial Council, the Labour members opposed a motion of loyalty and confidence in the government. ${ }^{37}$ When the SALP conference convened in East London in early January, there were strong signs of a takeover of the party by the anti-war left. Andrews appears to have been inwardly conflicted over his support of the parliamentary war resolution. His critique of the supposedly middle class composition of the League may have been something of a retrospective justification for the stance he had taken. Andrews began contributing to WoWL funds and speaking at their meetings. ${ }^{38}$ At East London, he turned to align himself with the War on War delegates, whose position was strengthened by the absence from the conference of Creswell, then on military service. In addition, the conference was enthused by the presence of the returned deportees. These included J.T. Bain, who had participated in some of the formative meetings of the anti-war Union of Democratic Control movement in London. ${ }^{39}$ (Bain could speak with some experience on matters of war and peace, having had the dubious distinction of having fought both in the British Army in the Sekhukhune and Zulu Wars and for the Boers in 1899-1900). ${ }^{40}$ The division in the SALP conference over the war was so deep, that it became clear that any definite decision risked splitting the party. The party treasurer, Gabriel Weinstock, engineered a compromise in which each member of the party was accorded "freedom of conscience" in relation to the war. ${ }^{41}$ Andrews' standing remained strong and he was re-elected as party chairman.

In February, speaking in Parliament, Andrews denounced the censorship of the Gazette, and went on attack the South-West Africa expedition as having provoked the Afrikaner rebellion:

I consider that the immediate cause of our troubles during the last three months has been the filibustering expedition to German South-West Africa. Under a misapprehension, I voted for that. I regret my vote and I would recall it if I could. The Government has the power to stop that expedition now, feeling perfectly secure. They hold the coast and the border, and there is no need to conquer that country. It is conquered, and it will not be a blessing to South Africa, but add to our difficulties in the future. ${ }^{42}$

With Andrews at the helm, the SALP executive took an anti-war course. In April 1915, the party addressed an appeal to the British socialist leader James Keir Hardie to convene an international socialist conference to discuss the terms of a peace settlement. ${ }^{43}$ In July, it sent a request to the British Labour Party to pressure the French Socialists into joining a socialist peace conference. ${ }^{44}$ But it is important to note that although the WoWL was following political events through the British, American and Italian socialist press, there was no real coordination of policy with comrades abroad. They were developing their own ideas in relative isolation, especially as the war disrupted normal travel and mail. ${ }^{45}$ The rhetoric of the War on War group had a real resonance in the labour movement. For example, at the Pretoria May Day celebration of the SALP and trade unions, City Councilor M.G. Nicolson told his audience that the time would come:

when all men would be as brothers, when capitalism and all its concomitant evils of poverty and disease, secret diplomacy and huge armaments and the exploitation of workers for profits would be no more. ${ }^{46}$

Meanwhile, the pro-imperial press and the pro-war faction of the party were growing increasingly enraged by the stance of the SALP executive and the League's agitation. In July, with the defeat of the German garrison in South-West Africa, Creswell, now with the rank of Major, returned home, determined to stage a show-down with his opponents. He issued a document which became known as the 'See it Through' manifesto, stressing South Africa's obligations to the Empire, and pushed for a conference to 
change the party's position on the war. In response, twenty leading members of the party published a document entitled 'The Labour Party's Duty in the War'. That duty was identified as "to agitate for a cessation of the fratricidal struggle to which the peoples of Europe have been blindly committed". It also declared its international loyalties in rousing terms:

We stand by international Socialism. We know it is faithful in all countries. In spite of the many failures and defections, in spite of the tremendous trial to which it has been put, in spite of the pressure of government and censorships and suppressions, of the lure of public office and applause, we exult in the fact that it is still a magnificent reality and will triumphantly emerge from the present dark hour, hereafter to become the one and only power that can emancipate the world from the savagery of its military and capitalistic machines. ${ }^{47}$

The signatories included seven provincial council members, amongst them Wade and Bunting; Reverend Hall; a number of prominent trade unionists - Andrews, Forrester Brown and Harry Haynes; and David Ivon Jones. The document was printed by the Eastern Record and its editors, the Barnets, were also amongst those who signed. ${ }^{48}$

\section{The International Socialist League}

On 22 August 1915, the SALP conference assembled in Johannesburg's Selborne Hall. In the view of the Andrews faction, Creswell had rigged the event by recruiting new members and establishing new branches. ${ }^{49}$ The growing radicalization of the anti-war group was reflected when Andrews opened with an attack on the party's existing policy of excluding black people from membership. But the main business was to be the discussion on war policy. Creswell was present, in full uniform. With Andrews in the chair, the Creswellites put forward a motion to support the South African and imperial governments in the war effort. Wade moved an amendment taking an anti-war position and opposing the planned dispatch of a South African military contingent to Europe, asking for the release of South Africa from imperial commitments and advocating cooperation with the international socialist movement for a just peace. After some debate, the Creswell faction demanded the putting of the question, which Andrews refused to do, amidst uproar. ${ }^{50}$ After Andrews was voted from the chair, a second replacement chair refused to cooperate, before a third chairman put the motion, which was passed 82 votes to $30 .{ }^{51}$

Andrews and his supporters stalked out singing 'The Red Flag'. Reconvening in a nearby office, they decided to form the International League of the South African Labour Party. However, the Creswellites now imposed a new loyalty oath on election candidates, and this effectively prohibited the internationalists from remaining in the party. The International League had now, in reality replaced the WoWL. On 22 September, 1915, its supporters met in the Trades Hall in central Johannesburg, where they founded a new party, the International Socialist League. Andrews was chairman, Weinstock treasurer, and David Ivon Jones, secretary; the management committee included Bunting and Dunbar. ${ }^{52}$

A general election took place soon afterwards, won by Botha. Creswell's SALP was reduced from 8 to 3 seats in parliament. Andrews and an ISL colleague stood in Johannesburg constituencies, where their meetings were relentlessly attacked by soldiers and pro-war civilians. They won only a few score votes each. ${ }^{53}$

The ISL was united against the war, but it now had to define where it stood on other questions. It was clear that it had little appeal to the British immigrant working class as a party, in the jingoistic 
atmosphere of the early war years. But in the longer run, the question of race loomed ahead. The ISL unanimously rejected the crude white labourism of Creswell. But they became almost immediately divided on the issue of how to approach the question of the political rights of the black working class. For Andrews, although in principle he favoured drawing black workers into trade union organisations, the realistic view was that the organized labour movement in South Africa was based amongst the white workers, and would continue to be so in the foreseeable future, so that was where the ISL should focus its attention. But for another faction, of which Bunting assumed the leadership, black workers were ripe for organization. Over the next few years ISL members played a significant role, along with dissident young members of the Native Congress, in initiating unions amongst black South Africans, especially the Industrial Workers of Africa (IWA) ${ }^{54}$ These organizations, like the ISL itself, had a strongly syndicalist flavor to their ideas. They played an important role in paving the way for the arrival in 1919 of the great black labour protest movement that was to dominate the South Africa of the 1920s, Clemens Kadalie's Industrial and Commercial Workers Union, the ICU.

\section{Conclusion}

The War on War League ultimately failed as a peace movement, because it was unable to win over the bulk of SALP voters, or to find any other source of support. There was a noteworthy gap between the leadership group of the SALP, where the anti-war position gained a strong following, and the ordinary members, for whom it had little appeal. The deeply felt critique of militarism put forward by the WoWL did not succeed in winning a large constituency. Nevertheless, the history of the League is an important in showing that in South Africa, as elsewhere in the British Empire, enthusiasm for the war was not universal in 1914-18. ${ }^{55}$ In South Africa, support for the war effort had to be actively built by the state, in the face of opposition, even within the British immigrant community. It needs to be stressed that even in the most loyal of settler colonies support for the war was not guaranteed - as was demonstrated by Australia's rejection of conscription in 1916 and 1917 referendums.

The assumption that the War on War League was historically significant only as a predecessor to the South African communism is teleological, anachronistic and narrowly national. Of all the War on War League's activists, it was really only Bunting, Andrews and David Ivon Jones who went on to play important roles in the Communist Party of South Africa. ${ }^{56}$ The others mostly drifted off in a range of political (and apolitical) directions. For the participants in the League at the time, the rejection of war was not a just political move, but a moment of ethical choice. And it was a decision that they thought through in terms of the universalist faiths of the pre-1914 world. The WoWL drew on the same ideological sources - socialist, but also Tolstoyan, liberal and Christian - as did pacifism in other countries, and needs to be understood as part of the global anti-war movements of the time.

But the movement did have some distinctly South African features. It was shaped by the recent experience of the Second Anglo-Boer War. The strong presence of veterans amongst the anti-war activists suggests that the trauma of that devastating conflict fed into a willingness among former soldiers to adopt a pacifist position. It is also striking that a powerful repudiation of nationalism was consistent theme of the WoWL - and here one might suggest the particularly blatant partisanship of first the Milner, and then the Smuts-Botha regimes, in favour of the mine owners and against immigrant British labour, was a factor that made the Rand's leftists particularly unsympathetic to the notion of a collective national interest. 
The League also helped to produce a more South African political identity amongst British immigrant political activists. In the labour struggles of 1913 and 1914, the Johannesburg leftists had often, ambiguously, denounced the established order, while at the same time demanding their rights as British subjects. No longer could they claim that position. The League moved toward speaking from a South African position, and this was manifested in the way in which they addressed the Boer rebels as fellow countrymen, and by the way in which some of their members moved to active organization of black workers.

The War on War League needs to be taken seriously by historians, not simply as a step toward something else, but as a moment in the international resistance to the Great War, and in South African history, in its own right.

1

David Ticktin, "The War Issue and the South African Labour Party 1914-1915", South African Historical Journal 1:1, 1969, 59-80, was the pioneer attempt to give an account of the movement. Sheridan Johns, Raising the Red Flag: The International Socialist League and the Communist Party of South Africa, 19141932 (Belleville, Mayibuye, 1995) also provides an analysis of the War on War League.

H.J. and R.E. Simons, Class and Colour in South Africa 1850-1950 (Harmondsworth, Penguin, 1969) is the classic statement of the position criticized in this article.

Lucien van der Walt, "The Industrial Union is the Embryo of the Socialist Commonwealth": The International Socialist League and Revolutionary Syndicalism in South Africa, 1915-1919", Comparative Studies of South Asia, Africa and the Middle East, 29,1, 1999, 5-28; Lucien van der Walt, 'Bakunin's Heirs in South Africa: Race and Revolutionary Socialism from the IWW to the International Socialist League, 1910-21"; Politikon: The South African Journal of Political Studies, 8,1, 2004, 67-89; Lucien van der Walt, "The First Globalisation and Transnational Labour Activism in Southern Africa: White Labourism, the IWW and the ICU, 1904-1934", African Studies, 66, 2/3, 2007, 233-251.

Adam Hochschild, To End All Wars: A Story of Protest and Patriotism in the First World War (London, Pan, 2012).

Gary B. Magee and Andrew S. Thompson, Empire and Globalization: Networks of People, Goods and Capital in the British World, c. 1850-1914 (Cambridge, Cambridge University Press, 2010).

Elaine N. Katz, A Trade Union Aristocracy: A History of White Workers in the Transvaal and the General Strike of 1913 (Johannesburg, African Studies Institute, 1976).

For my overview of this crisis moment, Jonathan Hyslop, "The Strange Death of Liberal England and the Strange Birth of Illiberal South Africa: British Trade Unionists, Indian Labourers and Afrikaner Rebels, 1910-1915", Review of Labour History, 79:1, 2014, 97-120.

Brain Willan, Sol Plaatje: A Biography (Johannesburg, Ravan, 1984).

For a brilliant analysis of the rebellion see Albert Grundlingh and Sandra Swart, Radelose Rebellie?: Dinamika van die 1914-1915 Afrikanerrebellie (Pretoria, Protea Boekhuis, 2009).

R.K. Cope, Comrade Bill: The Life and Times of W.H. Andrews, Workers' Leader (Cape Town, Stewart, 1944), 162.

Cope, Comrade Bill, 162.

Cope, Comrade Bill, 163.

Cope, Comrade Bill, 163.

Ruth Dudley Edwards, James Connolly (Dublin, Gill and Macmillan, 1981).

Alison Drew, Between Empire and Revolution: A Life of Sidney Bunting, 1873-1936 (London, Pickering and Chatto, 2007), 90.

Cope, Comrade Bill, 163.

War on War Gazette (hereafter WWG) 10 October 1914; Cope, Comrade Bill, 163.

The Workers' Educational Association (South Africa), Calendar 1914-15 (Johannesburg, WEA, 1914).

Cope, Comrade Bill, 163.

Cope, Comrade Bill, 163.

Cope, Comrade Bill, 163. 
Cope, Comrade Bill, 164.

National Archives of South Africa, Pretoria, SAP 6/245/14/50 Sergeant J. Lyons, Johannesburg to Subinspector, Johannesburg, 6 September 1914.

$W W G, 21$ November 1914.

Wilfrid H. Harrison, Memoirs of a Socialist in South Africa 1903-1947 (Cape Town, Stewart, c. 1947).

$W W G, 17$ October 1914.

$W W G, 24$ October 1914.

$W W G, 24$ October 1914.

$W W G, 24$ October 1914.

WWG, 14 November 1914.

WWG, 21 November 1914.

Cope, Comrade Bill, 166.

Cope, Comrade Bill, 166.

$W W G, 31$ October 1914.

$W W G, 31$ October 1914.

WWG, 14 November 1914.

Cope, Comrade Bill, 165.

Cope, Comrade Bill, 166.

Johannesburg Public Library, Strange Collection, SA Labour Party Papers, Notebook 3, leaflet for SALP open air meeting, East London, 31 December 1914. For Bain's activities in England during 1914 see his frequent contributions in The Worker and Eastern Record, 1914.

Jonathan Hyslop, 'Bain, James Thompson', in Oxford Dictionary of National Biography (online version) http://dx.doi.org/10.1093/ref:odnb/98502

Cope, Comrade Bill, 166.

Cope, Comrade Bill, 168.

Cope, Comrade Bill, 169.

Cope, Comrade Bill, 169.

Cope, Comrade Bill, 170.

Rand Daily Mail, 3 May 1915.

Cope, Comrade Bill, 171.

W.H. Andrews et.al., The Labour Party's Duty in the War: A Reply to the See it Through Policy (Benoni, Eastern Record, 1915).

Cope, Comrade Bill, 171-2.

Cope, Comrade Bill, 172.

Cope, Comrade Bill, 173.

Cope, Comrade Bill, 175.

Cope, Comrade Bill, 176-177.

See Drew, Bunting.

Niall Ferguson, The Pity of War (London, Penguin, 2009), does an interesting job of reversing the older views of popular attitudes to the First World War in Europe. Conventional wisdom tends to suggest that the war was overwhelmingly popular in all countries in 1914, but that later soldiers turned against it. Ferguson, on the other hand, argues that initial enthusiasm for the war has been greatly exaggerated, while, in his opinion, ordinary soldiers generally did not take as negative a view of their experience in the war as many now believe. For Ferguson, the anti-war soldier poets and writers who shaped the public's ideas about the conflict did not put forward a picture which was representative of their comrades' perceptions. While at one level these arguments reflect Ferguson's strategy of carving out a position for himself as a contrarian and a conservative scourge of liberal orthodoxy, the caution against simplistic generalizations about responses to the war is well taken.

Cope, Comrade Bill; Drew, Bunting; Baruch Hirson and Gwyn Williams, The Delegate for Africa: David Ivon Jones 1883-1924 (London, Core, 1995). 